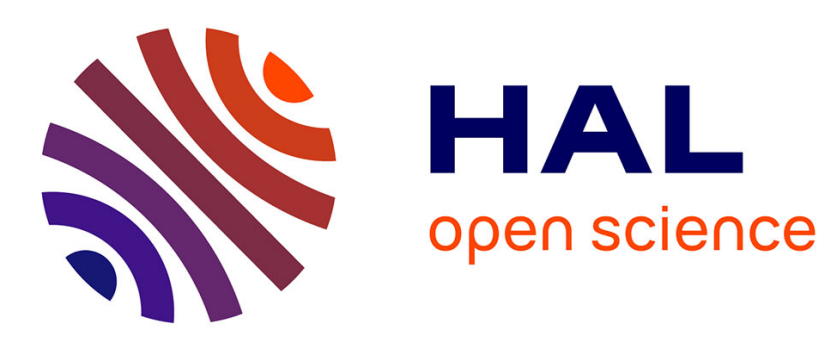

\title{
Abyssinia at al-Azhar: Muslim Students from the Horn of Africa in Late Medieval Cairo
}

\author{
Julien Loiseau
}

\section{To cite this version:}

Julien Loiseau. Abyssinia at al-Azhar: Muslim Students from the Horn of Africa in Late Medieval Cairo. Northeast African Studies, 2019, 19.1, pp.61-84. hal-02909953

\section{HAL Id: hal-02909953 \\ https://hal-amu.archives-ouvertes.fr/hal-02909953}

Submitted on 31 Jul 2020

HAL is a multi-disciplinary open access archive for the deposit and dissemination of scientific research documents, whether they are published or not. The documents may come from teaching and research institutions in France or abroad, or from public or private research centers.
L'archive ouverte pluridisciplinaire HAL, est destinée au dépôt et à la diffusion de documents scientifiques de niveau recherche, publiés ou non, émanant des établissements d'enseignement et de recherche français ou étrangers, des laboratoires publics ou privés. 
Julien Loiseau

Aix-Marseille Univ, CNRS, IREMAM ${ }^{1}$

\title{
Abyssinia at al-Azhar: \\ Muslim Students from the Horn of Africa in Late Medieval Cairo
}

\begin{abstract}
At the end of the fifteenth century, Muslim students from the Horn of Africa would come to Cairo in their search for knowledge and to dwell in the venerable mosque of al-Azhar. They formed a significant community of foreign students in the Egyptian metropolis, to the extent that they enjoyed their own fraternity where they gathered along their fellow countrymen. The article investigates the gradual development in Cairo of a Muslim community originating from the Horn of Africa. It puts their sudden visibility in the context of the establishment of the first student fraternities in al-Azhar's history. Finally, it questions their role in the growing connections between Egypt and the Horn of Africa in the later Middle Ages.
\end{abstract}

\section{Introduction. A Family Trajectory from the Horn of Africa to Egypt}

Amidst the literary legacy of Ottoman Egypt stands a major historical work written in the beginning of the nineteenth century, which is a firsthand testimony on the time of the French expedition (1798-1801 CE) and the first half of Muhammad 'Alī's reign as Egypt's pasha (18051848 CE): 'Ajā'ib al-āthār fi l-tarājim wa l-akhbār (The Wonders of the Remnants in Biographies and Stories). Its author was such an Egyptian figure, educated in Cairo at the al-Azhar mosque, and today in the hall of fame of Egyptian national literature, that one often forgets his background and family history. Born in Cairo in $1167 \mathrm{AH} / 1753 \mathrm{CE}$, died in the same city in $1241 \mathrm{AH} / 1825 \mathrm{CE}$, al-Gabartī was the seventh-generation offspring, and also the namesake, of one 'Abd al-Raḥmān al-Zayla'ī al-Jabartī, who left the Horn of Africa at the end of the fifteenth century. ${ }^{2}$ The nisba or relation name "al-Jabartī" (pronounced "al-Gabartī" in Egyptian colloquial Arabic) was borne by his descendants in Egypt for more than three centuries. It recalls the ancestor's homeland, the Bilād al-Jabart, which his scion, writing at the beginning of the nineteenth century, describes as follows ${ }^{3}$ : "The country of Jabart, or country of Zayla', ${ }^{4}$ is in the territories of the Abyssinians under the reign of the Hațī, king of the Abyssinians. ${ }^{5}$ It includes different places, which are well known and are inhabited by this people who are Muslims in these areas and follow the Hanafì and Shāfi'i schools only." Rather than a continuous territory, the "Country of Jabart" has to be understood as an inclusive place name covering several areas inhabited by Muslim peoples in present Eritrea, eastern Ethiopia, and Somalia, as well as a 
geographical category encompassing all the Muslims in the Horn of Africa. ${ }^{6}$ Be that as it may, the success story of the family's forefather, born in the "Country of Jabart," is known in some details thanks to his descendant, who summarized in his book the history of the seven generations of alJabartīs in Cairo, in the obituary notice dedicated to his own father, who died in $1188 \mathrm{AH} / 1774$ CE. ${ }^{7}$ The ancestor left his native country in the Horn of Africa and crossed the sea to Jeddah, the harbor of Mecca, on the western coast of the Arabian Peninsula. He settled in the sanctuary (haram) of Mecca and performed the hajj several times, which means that he lived in the holy city for several years. 'Abd al-Rahmann moved later to Medina and he settled for two years in the vicinity of the Mosque of the Prophet. He took advantage of his stay as a permanent resident (mujāwir) in the two holy sanctuaries to learn from several masters. Moving back to Jeddah, 'Abd al-Rahmān traveled along the Egyptian pilgrimage route, through Suez (al-Qulzum), and finally arrived in Cairo at the beginning of the tenth century AH, last years of the fifteenth century CE. This is the only date of 'Abd al-Rahmmān's biography recorded by his descendant, who does not mention the date of his death in Cairo. Hence, we do not know how many years had elapsed since he left the Horn of Africa.

During his several years in the sanctuaries of Mecca and Medina, al-Jabartī relied upon an institution that would take care of his fellow pilgrims from the Horn of Africa: the riwāq of the "people of Jabart" (Riwāq al-Jabartiyya). In Islamic architecture, a riwāq is a portico along the courtyard of a mosque. In this instance, however, it stands for a living quarter where "the poor in God" (al-fuqarā'), either sufis or students who cannot afford housing, could settle on a temporary or permanent basis. ${ }^{8}$ Moreover, its restriction to people sharing the same homeland (in this case, the "Country of Jabart") suggests that arwiqa (sing. riwāq) in Mecca and Medina were run as fraternities open to pilgrims on the basis of their common origin and devoted to their material and spiritual support. ${ }^{9}$ Indeed, the two holy cities attracted a wide range of people from the whole Islamic world during the hajj season: some of them settled for years in the vicinity of the two sanctuaries seeking blessings and knowledge. Given the current state of evidence, however, it is unclear how many arwiqa were open at that time in Mecca and Medina for pilgrims of foreign origin; in other words, if the "people of Jabart" were the only ones in the late fifteenth century to enjoy its own riwāq in the holy cities. Visiting Mecca disguised as a Muslim pilgrim in 1503, the Italian traveler Ludovico di Varthema points out the "great number of pilgrims, of whom some came from Ethiopia, some from India Major, some from India Minor, some from Persia, and some from Syria. ${ }^{10}$ Hence Muslims from the Horn of Africa were at that time among the best represented peoples in Mecca during the hajj ceremonies, along with the Egyptian and sub-Saharan pilgrims who came with Egyptian caravans.

Upon arrival in Cairo with the Egyptian pilgrim caravan, al-Jabartī took advantage of the same charitable institution, a riwāq and its facilities for his fellow countrymen established in the mosque of al-Azhar. He eventually became the head (shaykh) of the Riwāq al-Jabartiyya in al- 
Azhar, got married, and left a son when he died in Cairo. The office of "shaykh al-Jabartiyya" was handed down to his son and kept by his descendants until the nineteenth century and his famous namesake, the historian 'Abd al-Raḥmān al-Gabartī. This family trajectory has been until now interpreted as a starting point, a piece of evidence, of the presence of people from the Horn of Africa in Ottoman Cairo starting in the sixteenth century. ${ }^{11}$ But a riwāq devoted to the "people of Jabart" was already operating in Mecca, Medina, and Cairo in the late fifteenth century. Indeed, 'Abd al-Raḥmān al-Jabartī was the first in his family to head their riwāq in Cairo, but there is no evidence that he was the first shaykh of the Jabartiyya students in al-Azhar. The aim of this article is to collect the few pieces of evidence that exist of Muslim students from the Horn of Africa living in Cairo prior to Ottoman times.

\section{Al-Azhar 1415}

\section{Al-Azhar's Permanent Residents}

In medieval Islamic cities, the management (nazar) of pious institutions was usually entrusted to the highest officers of the Islamic law: in Cairo, to the Shäfi $\bar{T}$ chief-judge and his deputies. However, from the second half of the fourteenth century onwards, Mamluk sultans and amirs gave preference to Mamluk military officers to oversee of their own pious foundations. At a time of growing economic and political crisis in the Mamluk kingdom, the latter appeared better able to enforce the provisions of waqf deeds and defend the institutions' integrity against encroachment and confiscation, than law officers or other civilian notables. Even the most prestigious foundations were entrusted by the Mamluk authorities to Mamluk officers: in the fifteenth century, the commander-in-chief (atābak al-'asākir) of the Egyptian armies, for instance, the highest officer of the Mamluk state after the sultan himself, was customarily appointed as trustee (nāẓir) of al-Manșūr Qalāwūn's hospital (al-Māristān al-manșūrī). ${ }^{12}$

In Jumādā II 818 AH/August 1415 CE, the Mamluk amir Sūdūn al-Ẓāhirī, who was at that time Cairo's great chamberlain (hājib al-ḥujjāb) and as such in charge of military justice (which might have earned him the nickname of "al-Qāḍī," the Judge), became the trustee (nāẓir) of alAzhar mosque. ${ }^{13}$ Opened in $361 \mathrm{AH} / 972 \mathrm{CE}$, three years after the foundation of al-Qāhira, the new capital of the Fatimid caliphate in Egypt, al-Azhar was one the oldest religious institutions in Cairo. Rumors of indecent acts among the permanent residents (mujāwirūn) spending the night in alAzhar prompted the new trustee to expel the latter from the mosque. Contradicting its wellestablished tradition, the amir and his henchmen violently ousted al-Azhar's residents at night, threw away their chests (sanādiq) and lockers (khazä'in) on the pretext that they were cluttering the prayer halls, and plundered their possessions. The events were recorded by two Cairene chroniclers. ${ }^{14}$ 
At that time, according to al-Maqrīzi (766-845 AH/1364-1442 CE), there were about 750 "poor in God" (fuqarä'), meaning students and/or sufis, established in al-Azhar for nights of prayer or years of study. ${ }^{15}$ The high number of permanent residents might have reflected the growing reputation of the mosque as a place of worship and study at that time. But this was new in the long history of al-Azhar. Its unique role and status in Fatimid Ismaili Egypt until the twelfth century as well as in Ottoman Sunni Egypt from the sixteenth century onwards should not overshadow its decline and relegation. In $567 \mathrm{AH} / 1171 \mathrm{CE}$, following the fall of the Fatimid caliphate, Friday worship was interrupted in al-Azhar on Saladin's order. In strict compliance with Shāfi î law, worshippers had henceforth to attend the prayer in one place: al-Hākim mosque in Cairo, 'Amr mosque in Fusțāț. ${ }^{16}$ Al-Azhar reopened for Friday worship in 665 AH/1266 CE after being restored and refurbished. For the first time in its history, teachings in Sunni Shäfi îlaw and prophetic tradition (hadith) were also established, along with Quranic recitations: the mosque was ready to host its first students since the official abandonment of Ismailism. ${ }^{17}$ In the Fourteenth century, however, the most famous scholars were not teaching in al-Azhar, despite its extension and embellishment thanks to the recent patronage of Mamluk amirs, but rather in the main madrasas of the city, such as the Shaykhūniyya established in $756 \mathrm{AH} / 1355 \mathrm{CE} .{ }^{18}$ Even the sultan's involvement in the patronage of the mosque, beginning with al-Z̄āhir Barqūq's rebuilding of its minaret in $800 \mathrm{AH} / 1397 \mathrm{CE}$, did not critically enhance al-Azhar's position. ${ }^{19}$ The gradual development of an Azharian milieu among Cairene scholars does not predate the fifteenth century. Evidence may be found in the vast biographical dictionary of al-Sakhāwī (830$902 \mathrm{AH} / 1427-1497 \mathrm{CE}$ ) devoted to the people of the ninth century AH/fifteenth century CE. ${ }^{20}$ Half a century later, the comprehensive picture of Egyptian Sufism provided by al-Sha'rānī (14911565 CE) in his Tabaqāt kubrā highlights the recent promotion of al-Azhar in the learning path of Cairene sufis. ${ }^{21}$

At the time of their expulsion in $818 \mathrm{AH} / 1415 \mathrm{CE}$, the high number of permanent residents in al-Azhar might have reflected the poverty that prevailed among students, because the country was just recovering from the disasters of the beginning of the fifteenth century: wars, plagues, and droughts, which exacerbated the long-term decline of the Egyptian economy and ruined most of the pious foundations devoted to sustaining the poor in Cairo. ${ }^{22}$ The old mosque had become a refuge for the "poor in God" in harsh times. Pious almsgivers carried on endowing waqfs to provide bread for the "poor residents" (al-fuqarā' al-mujāwirūn) of al-Azhar throughout the fifteenth century. ${ }^{23}$

\section{Al-Azhar's Student Fraternities}

According to the unique testimony of al-Maqrīzī, the permanent residents expelled from al-Azhar in $818 \mathrm{AH} / 1415 \mathrm{CE}$ belonged to four different communities (ță'ifa): "Ajam" (Persian speakers coming from Anatolia and eastern Islamic lands), "Zayāli'a" (coming from Zayla', in the 
Horn of Africa), natives of the "Rîf Mișr" (the Nile Delta) and "Maghāriba" (coming from North Africa). Each community was provided with a riwāq for its exclusive use within the walls of the mosque. ${ }^{24}$ This passage in al-Maqrīī's Khițțt is all the more important because it was the first comprehensive description of al-Azhar fraternities institution (niz̄ām al-arwiqqa). Student fraternities in al-Azhar in Ottoman times have been thoroughly studied. ${ }^{25}$ In the mid-seventeenth century, the institution consisted of fourteen fraternities based on the students' legal schools, languages, or native countries, and enjoying their own spaces and facilities inside the mosque. At its climax of the nineteenth century, it included seventeen living quarters for foreign students, not counting quarters for various Egyptian fraternities. ${ }^{26}$ However, its development in its early stages remains unclear. ${ }^{27}$

The teaching circle in Mālikī law held "in the living quarter of the Maghrebians (riwāq alMaghāriba) in the mosque of al-Azhar" by a Maghrebian shaykh (who died in 799 AH/1396 CE) might be the earliest explicit evidence of the institution. ${ }^{28}$ The fact that the Maghrebian scholar Ibn Khaldūn, newly arrived in Cairo in Dhū I-Qa'da 784 AH/January 1383 CE, and who was promptly requested to teach by students (țalabat al-ilm), gave his first lecture in al-Azhar, suggests that Maghrebians were already well-established in the mosque. ${ }^{29}$ In the year $784 \mathrm{AH} / 1383 \mathrm{CE}$, the sultan issued a decree (marsūm) allowing al-Azhar's permanent residents (mujāwirūn) to keep in the mosque the belongings of their fellow students in case they die without a legal heir among their kin. ${ }^{30}$ It is likely that the decree, later engraved in stone and displayed at the mosque's main door, resulted from a petition from the residents, which suggests that an internal organization had been set up by the early 1380 s CE. Testimony of students permanently established in al-Azhar even goes back as early as 756 AH/1355 CE according to a waqf deed that provided for monthly bread distribution to its "poor residents." ${ }^{31}$ But there is no evidence that any riwāq had been already established at that time. The events of $818 \mathrm{AH} / 1415 \mathrm{CE}$ are to my knowledge the first instance in which student fraternities are traceable in al-Azhar.

It can be assumed that, in the early internal organization of al-Azhar's students, the availability of a riwāq and the gathering of a community (ță'ifa) on the basis of school, language and/or origin, were closely related. ${ }^{32}$ Student fraternities were the result of the combination of a common identity and material facilities intended to support it. However, the former should not be too rigidly interpreted. It is likely that the origins and cultural identities of al-Azhar students in $818 \mathrm{AH} / 1415 \mathrm{CE}$ were much more varied than the four communities they were grouped in by al-Maqrīzī. The isolated nature of the latter's testimony requires additional evidence.

The above-mentioned dictionary of al-Sakhāwī provides a quite different picture of alAzhar fraternities in the fifteenth century, as shown in its more than 11,000 biographical notices. ${ }^{33}$ Four different arwiqa are evidenced in the Daw' al-Lāmi'. The Nile Delta natives' fraternity (Riwāq al-Riyāfa) is the most frequently mentioned with seven instances; the names of three of its successive heads (shaykh) are even recorded. ${ }^{34}$ There is nothing surprising about the 
higher visibility of this first Egyptian student fraternity. The Cairene chronicler al-Șayrafi (819$900 \mathrm{AH} / 1416-1495 \mathrm{CE}$ ) also mocked the "peasants who permanently dwell (al-fallāhūn almujāwirūn) in al-Azhar mosque." ${ }^{35}$ The second fraternity, in terms of the number of mentions in al-Sakhāwī's dictionary is the Riwāq Ibn Ma'mar. ${ }^{36}$ I have been unable to identify the eponymous figure of this fraternity, assuming that Ibn Ma'mar was actually a historical figure. But it is worth noting that one of the Riwāq Ibn Ma'mar's heads (shaykh) and two of its residents were natives of Gharbiyya, an Egyptian province in the center of the Nile Delta. It is also an Egyptian student born in Ziftā, Gharbiyya, in 830 AH/1427 CE whose notice provides the unique mention of the Riwāq al-Yamna. ${ }^{37}$ Was this fraternity linked to the Yemen as its name suggests? Yemeni students did form a community at the end of the fifteenth century, according to an inscription recording the endowment of a locker (khizāna) to benefit of the "Yemeni residents" (al-mujāwirūn alyamaniyya) in al-Azhar. ${ }^{38}$ Furthermore, the above-mentioned Egyptian resident of the Riwāq alYamna later left al-Azhar for Aden, Yemen, where he worked as a merchant during almost forty years: the fraternity's networks may have played a role in his second career abroad. The fact that he was known in Aden as "al-Ṣa 'īdī," i.e., as a native of Upper Egypt (al-Ṣa'īd), should prompt us however to be cautious when assigning identity: his family may have been rooted in Upper Egypt before dwelling in Ziftā, Gharbiyya.

Al-Sakhāwī's dictionary finally provides evidence of a fourth fraternity in fifteenth-century al-Azhar: the Riwāq al-Jabart, mentioned three times in connection with two different figures. ${ }^{39}$ The first one was born in al-Ushmūnayn in Upper Egypt in $857 \mathrm{AH} / 1453 \mathrm{CE}$ and later dwelt in the Riwāq al-Jabart of al-Azhar while studying law (fiqh): he ended up affiliated with the Māliki law school and had a career as judge's deputy in Būlāq, the Nile port of Cairo. The second one was still alive in 895 AH/1490 CE when al-Sakhāwī met him: born in Dhirwa, a village in Upper Egypt, he lived in poverty throughout his life and was revered by some of his contemporaries. Nicknamed as the "Resident (nazīl) of the Riwāq al-Jabart," it is most likely that he never left alAzhar. Dedicated to students from the Horn of Africa, the al-Jabart fraternity in al-Azhar, if its name is credible, seems to have maintained a long connection with Upper Egypt.

It is hard to assume that the four fraternities evidenced by al-Sakhāwī's fifteenth-century biographies exactly matched the four arwiqa described by al-Maqrīī for the year $818 \mathrm{AH} / 1415$ CE. However, it is worth noting that according to both testimonies, natives of the Nile Delta (riyāfa) as well as students from the Horn of Africa (zayāli 'a, jabartiyya) did enjoy their own living quarters and fraternities in al-Azhar. There is nothing surprising about the fact that residents of various origins lived in the same riwāq. Egyptian students made up a large majority of al-Azhar permanent residents and used the facilities of the four arwiqa mentioned by al-Sakhāwī. But it is no coincidence if natives of Upper Egypt found their way to the Riwāq al-Jabart, considering the long-standing connections between the southern provinces of Egypt and the Horn of Africa. Whatever was the exact number of fraternities in al-Azhar at the end of the fifteenth century, ${ }^{40}$ 
and whoever were their actual residents, the mere existence of the Riwāq al-Jabart (or Riwāq alZayāli'a) is a clear indication of the visibility in Cairo of Muslim students from the Horn of Africa. As early as $818 \mathrm{AH} / 1415 \mathrm{CE}$, almost a century before the coming of al-Gabartī's ancestor, they already formed one of the most visible communities of foreign students in Cairo.

\section{Before the Azharian Fraternity. Zayāli 'a and Jabartiyya in Fourteenth-Century Cairo}

Abyssinians (habasha) have been familiar figures in Egypt and the Middle East for centuries. ${ }^{41}$ In fourteenth-century Cairo, individuals bearing the nisba, or relation name, "alHabashī" ("the Abyssinian") were either Christian monks and clerics coming from the Christian kingdom of Ethiopia, or slaves of pagan (and sometime of Christian) origin imported from the Horn of Africa. Some of the latter, freed by their masters, made a successful career, especially eunuchs with whom the Mamluk authorities entrusted sensitive positions closely related to the sultan (his treasure, harem, or body, alive as well as dead)..$^{42}$ However, Muslims from the Horn of Africa freely arrived in Egypt, bearing either the nisba "al-Zayla'ī" (related to Zayla', in present Somaliland) or "al-Jabartī" (related to the Country of Jabart), were newcomers at that time. ${ }^{43}$

Arriving in Cairo in 705 AH/1305-1306 CE, Fakhr al-Dīn 'Uthmān b. 'Alī b. Yaḥyā b. Yūnus al-Zayla'i might have been one of the earliest men of Zayla' to be known under that name in Egypt. ${ }^{44} \mathrm{His}$ fame, which earned him the privilege to appear in the History of Egypt and Cairo of al-Suyūți (849-911 AH/1445-1505 CE) alongside the most renowned scholars of the Hanafĩ school of law in Egypt, was mainly due to his Kitāb Tabyin al-haqā'iq, a commentary of the Kanz aldaqa'iq, a compendium of Hanafī jurisprudence written by 'Abd Allāh b. Aḥmad al-Nasafī (d. $710 \mathrm{AH} / 1310 \mathrm{CE}$ ). ${ }^{45} \mathrm{He}$ died in $743 \mathrm{AH} / 1343 \mathrm{CE}$, and his grave in al-Qarāfa, the vast necropolis of Cairo, has been remembered for centuries, to the extent that an epitaph was carved to his memory in the Ottoman period, partly quoting his biography by al-Suyūțī. ${ }^{46}$ In his lifetime, 'Uthmān al-Zayla'ī counted among his students a fellow countryman, Jamāl al-Dīn 'Abd Allāh b. Yūsuf b. Muhammad al-Ḥanafĩ al-Zayla'ī (d. 762 AH/1360 CE), who was also recorded by alSuyūțī as one of the masters of the Prophetic tradition (hâfiz al-hadīth) in Egypt. ${ }^{47}$ We do not know, however, in which institution(s) the master and the pupil actually met in Cairo, but it might have been in the Khānqāh al-Țquzdamuriyya, in al-Qarāfa necropolis, which had been headed for a while by the former ${ }^{48}$.

The nisba "al-Jabartī" seems to appear later in the Egyptian documentation, ${ }^{49}$ and remains frequently associated with the nisba al-Zayla ī. One of the earliest figures known in Cairo under this name might have been 'Abd Allāh al-Jabartī al-Zayla'ī, died in Muharram 780 AH/May 1378 CE. ${ }^{50}$ Revered in his lifetime by his contemporaries and considered a saint ("min 'ibād Allāh al-șāliḥin"), the shaykh 'Abd Allāh was buried in the zāwiya he established in the necropolis of alQarāfa and his grave soon became a place of pious visitation (ziyāra). His zāwiya remained a lively 
institution throughout the fifteenth century, but there is no evidence that it was expressly frequented by Muslims from the Horn of Africa. ${ }^{51}$ Conversely, the offices of imām and teacher in the Turbat al-Sitt, another institution of the necropolis, had been handed down from father to son within a family of Jabartiyya scholars in the late fourteenth century, without evidence of connection between this place and people from the Horn of Africa. ${ }^{52}$ As early as the 1390 s, however, on the sultan's order the holy body of 'Abd Allāh al-Jabartī al-Zayla'ī was removed from his grave and reburied in the northern necropolis of al-Ṣaḥrā'. At that time, al-Ẓāhir Barqūq (r. 784-801 AH/1382-1399 CE) was preparing for his death by transporting the remains of several holy men he revered to the place of his future grave. ${ }^{53} \mathrm{His}$ devotion towards Shaykh 'Abd Allāh was well-known among the Jabartiyya in Cairo, to the extent that it was recalled four centuries later by 'Abd al-Raḥmān al-Gabartī in his 'Ajā'ib al-āthār. ${ }^{54}$

Shaykh 'Abd Allāh was not the only figure of northeastern Africa in Egyptian Sufism at that time. ${ }^{55}$ Apart from the case of former Abyssinian slaves converted to Islam, such as the prominent shaykh of the Shādhiliyya Yāqūt al-Habashī (d. 732 AH/1332 CE), ${ }^{56}$ Zayāli'a or Jabartiyya freeborn Muslims also appeared in late fourteenth-century Șūfī networks. During the sacred month of Ramaḍān 780 AH/December 1378-January 1379 CE, a "holy man" ("min ahl al-ṣalāḥ") named 'Abd Allāh al-Zayla'ī (not to be confused with the Shaykh 'Abd Allāh, who died several months before) was involved in the closing of a church in the province of Gizeh near Cairo, after having appealed to the highest Mamluk authorities: he was later allowed to convert the church into a mosque. ${ }^{57}$ In $793 \mathrm{AH} / 1390 \mathrm{CE}$, soon after his return from the hajj, a follower of the Șūfi leader Muḥammad Ibn al-Wafā al-Iskandarī named Muḥammad al-Zayla'ī, died in Cairo: he was buried close to his master's tomb in al-Qarāfa necropolis. ${ }^{58}$

At the turn of the century, freeborn Muslims from the Horn of Africa were already prominent in Egyptian Șūfi circles and institutions, as evidenced by their increasing number of appearances in obituary notices and biographical dictionaries compiled in Cairo. Their sudden appearance in $818 \mathrm{AH} / 1415 \mathrm{CE}$ as an established community in al-Azhar, enjoying its own living quarters and student fraternity, would be inexplicable without their growing presence and the increasing number of notable individuals among them during the last decades of the fourteenth century.

\section{Abyssinia, al-Azhar, and Mamluk Diplomacy}

\section{Two Abyssinian Eunuchs}

The expulsion of al-Azhar's permanent residents (mujāwirūn) in $818 \mathrm{AH} / 1415 \mathrm{CE}$ by the Mamluk amir Sūdūn al-Qāọī, acting as the mosque's trustee, was not followed up. Two decades later, a community of Zayālia/Jabartiyya students was again dwelling in the mosque. In 840 $\mathrm{AH} / 1436 \mathrm{CE}$, one of the most prominent officers of Sultan al-Ashraf Barsbāy's reign (r. 825-841 
$\mathrm{AH} / 1422-1438 \mathrm{CE}$ ), the great intendant of the royal princesses (zimām al-ādur al-sharifa), Jawhar al-Lālā added new assets to his wealthy pious foundation (waqf). ${ }^{59}$ Owner of two buildings in the vicinity of al-Azhar, he decided to make them waqf and assign their income to different pious purposes: pensions for six orphans and their teacher; an expenditure for a small zāwiya near his residence; and finally, each year in the beginning of the sacred month of Ramaḍan, 5,000 copper dirhams "for the poor and travelers among the people of Zayla' and Jabart who are living as permanent residents (mujāwirūn) in the living quarter (riwāq) of the Zayāli'a at al-Azhar."60 Archive documents also provide evidence of the continuous activity of this student fraternity in the fifteenth century.

Jawhar al-Lālā was a eunuch of Abyssinian origin (habashĩ al-jins), castrated in his youth, sold in Mecca to a Mamluk amir, and grew up in Cairo before he entered the domestic service of the sultan. ${ }^{61}$ There is nothing surprising in the prominent positions reached by Abyssinian eunuchs in the Mamluk kingdom, even if no one had been as powerful as Jawhar al-Lālā at the end of Barsbāy's reign and under the short rule of his son (841-842 AH/1438 CE). ${ }^{62}$ But it is worth noting that a former slave who had neither past nor family felt in some way responsible of the well-being of people who were not, truly speaking, his fellowmen. Jawhar al-Lālā was born a pagan or a Christian, and later converted to Islam after he had been enslaved and castrated. This did not prevent him from acting as a patron for the Muslim students who freely came to Cairo from the Horn of Africa. Because the patronage of Jawhar al-Lālā was not motivated by a shared origin or identity (we do not know if he spoke the same native language as al-Azhar's Zayāli'a), explanations must lie elsewhere. His almost brother, the eunuch Jawhar al-Qunuqbā'î, had a slightly different story. Born a pagan, enslaved and castrated in the Christian kingdom of Ethiopia, he was offered in 788 AH/1386-1387 CE as a diplomatic gift to Sultan al-Zāair Barqūq by the Abyssinian king Dawit (r. 1379-1414 CE). He later made a career in the service of various amirs before entering the sultan's house as treasurer (khāzindār) thanks to the support of Jawhar alLālā. ${ }^{63}$ In 842 AH/1439 CE, Jawhar al-Qunuqbā'ī built a funerary madrasa intended for his grave along the northeastern wall of al-Azhar, the door and windows of which opened inside the courtyard of the mosque. ${ }^{64}$ As the waqf deed of Jawhar al-Qunuqbā'i has not been preserved, one can hardly assume that the place was supposed to be attended by the Zayāli'a of al-Azhar. But it would not have been unlikely if the latter's living quarters were somehow connected to Jawhar's funerary madrasa.

\section{A Diplomatic Letter from Abyssinia}

The relationships between the Abyssinian eunuchs and al-Azhar's residents from the Horn of Africa are clarified by another piece of evidence. In 847 AH/1443 CE, an embassy came to Cairo from Abyssinia, sent by King Zära Ya'eqob (r. 1434-1468 CE) for the second time in six years, after almost half a century without official relations between the two kingdoms. ${ }^{65}$ The embassy was 
led as usual by two men: a member of the Amhara Christian nobility and a Muslim slave trader. The text of Zära Ya'eqob's letter, most likely originally written in Arabic, has been preserved in this language with slight differences by two Cairene chroniclers, giving a detailed account of the king's claims and demands. ${ }^{66}$

Most of the letter is devoted to the situation of the Christian subjects of the sultan, their tribulations either in Egypt or Jerusalem, and the protection the Abyssinian king intends to provide them. Zära Ya'eqob also stresses the fact that a great number of Muslims are living in his kingdom, that their cities and trade are under his protection, that their "sultans" obey him, and that, conversely, these people and their business could be subject to retaliation. The letter twice mentions that if the Mamluk sultan would like confirmation of the king's claims, there are people to attest to their truth. First mentioned are "the merchants and those who use to go back and forth to our country," whose regular journeys keep them informed of Abyssinia's affairs. Later in the text, the king also advises the sultan to "ask the Jabartiyya who are dwelling (muqimūn) in the mosque of al-Azhar, since their sultan is a Muslim." ${ }^{\prime 67}$

In $847 \mathrm{AH} / 1443 \mathrm{CE}$, the presence of Muslim students from the Horn of Africa in al-Azhar was not only well-known at the court of the Christian Abyssinian king. This community was also involved in the relationships between the king and the Mamluk sultan. Strongly established in a learning institution that was becoming one of the most important in Egypt, enjoying one of the oldest student fraternities in town, the Jabartiyya were no longer individuals scattered in the underworld of Egyptian sufism but had become a collective agent of the Mamluk diplomatic scene. Moreover, they were also considered well-informed about what happens in their native country, as were merchants trading with the Christian kingdom, suggesting that they were regularly interacting with their family and relatives. Hence al-Azhar had given rise in the fifteenth century to a new diaspora from the Horn of Africa.

\section{The Șūfi, the Sultan, the Eunuchs and the Merchants}

In the later Middle Ages, the dissemination of information was still shaped by the movement of goods, as well as diplomacy was shaped by trade. Most of the time, Abyssinian embassies to Cairo used the land and sea routes of the merchants, and were even co-led by them. ${ }^{68}$ Besides, the fifteenth century saw a growing integration of the Red Sea trade within the Mamluk realm at the expense of the Rasulid Yemen, connecting ever more strongly the ports and

cities of western Arabia to Cairo. ${ }^{69}$ The increasing connections of the Zayāli'a/Jabartiyya students of al-Azhar might have been linked to this major shift in the pattern of Red Sea trade and navigation. At least it is what the life and activities of a famous Jabartī resident of fifteenthcentury al-Azhar suggests. 
'Alī ibn Yūsuf al-Jabartī al-Azharī al-Muqri' arrived in Cairo in the 1440s, where he was trained in Coranic lectures and hadith. In 866 AH/1461-1462 CE, he left the city in order to pursue his quest for knowledge: first in Damascus, then in Baghdad (temporarily leaving the Mamluk kingdom) where he was affiliated with the Qadiriyya Șūfĩ brotherhood, and finally in Aleppo where he lived for two years. In 870 AH/1465-1466 CE, 'Alī al-Jabartī was back in Cairo and got married, but nevertheless dwelt alone in a cell on the roof (sațh) of al-Azhar. His accommodation earned him the nickname of the "Inhabitant of the mosque's roof " ("nazil saṭ̣ Jāmi 'al-Azhar"). ${ }^{70}$ It is difficult to say how many were seeking solitude on al-Azhar's roof or elsewhere in the mosque. But a hermit hardly stays alone for long and the reputation of 'Alī al-Jabartī soon attracted disciples. In addition to the students seeking to learn his seven lectures of the Coran, ${ }^{71}$ several eunuchs, probably Abyssinian, used to follow him. In addition to his academic activities, 'Alī al-Jabartī was investing (along with his followers) in the businesses of the merchants he knew. ${ }^{72}$ One knows the role played by Aleppo in the spice trade in connection with Venetian networks and merchants. ${ }^{73}$ One also knows, because of the career of Jawhar al-Lālā and Jawhar al-Qunuqbā'î, the growing involvement of eunuchs of the sultan's house in the affairs of the Red Sea. ${ }^{74}$ Indeed, there is nothing surprising about Jabartī holy man forming a link between Abyssinian eunuchs and Syrian merchants, and who may well also be acting as a broker. Only the place of their talks, on the top of al-Azhar's roof, might seem a little incongruous.

Writing at the beginning of the nineteenth century and wishing to illustrate the fourcentury-long history of his fellow countrymen in al-Azhar, 'Abd al-Raḥmān al-Gabartī also recalled the story of the "inhabitant of the mosque's roof." According to his highly embroidered account, the famous Jabartī holy man was followed by Sultan al-Ashraf Qāytbāy himself (r. 872-901 $\mathrm{AH} / 1468-1496 \mathrm{CE})$, who used to visit him and showed to him the same reverence that Sultan alZ̄āhir Barqūq (r. 784-801 AH/1382-1399 CE) showed to 'Abd Allāh al-Jabartī a century earlier. The story was actually more than a popular tale among the Jabartiyya of al-Azhar, because the shaykh was buried in a mosque adjacent to Qāytbāy's funerary complex. ${ }^{75}$ But one knows also that in $881 \mathrm{AH} / 1476 \mathrm{CE}$ the sultan ordered the parasitical structures that had been built in al-Azhar, namely the cells established on top of the mosque's roof, to be razed. ${ }^{76}{ }^{\prime} t^{\prime}$ 's unclear if 'Ali alJabartī was still alive at that time and bore the brunt of Qāytbāy's decision. ${ }^{77}$

\section{Conclusion}

From the early fourteenth century onwards, the presence of freeborn Muslims from the Horn of Africa had been noticeable in Cairo due to the successful careers of some of their countrymen. In addition to other students and scholars from the Islamic world, they had been increasingly attracted by its countless learning institutions and the presence of the great masters of the time. At the turn of the century, however, the increasing number of figures from the same background in Egyptian Șūfi networks and the sudden appearance of the "Zayālia"a" among the 
most visible foreign student communities in Cairo show a change of scale. This change may have been related to the growing integration of the Red Sea trade in Egyptian networks. Muslims from the Horn of Africa were now in position to enlarge their horizons beyond Yemen and the Hijaz. But this change in scale also has to do with the larger diffusion of Islam among the peoples of eastern Ethiopia. The gradual substitution of "Jabart" for "Zayla" as common reference for the designation of Muslim people from the Horn (either in their personal nisba or their collective name) was likely the result from this ongoing process. The growing connection between the Horn of Africa and the Middle East could not be more evident than in the crowded hallways of al-Azhar.

\footnotetext{
${ }^{1}$ This paper is part of the ERC COG project HornEast that has received funding from the European Research Council (ERC) under the European Union's Horizon 2020 research and innovation program (Grant Agreement No. 726206).

2 David Ayalon, "The Historian al-Jabartī and his Background," Bulletin of the School of Oriental and African Studies 23 (1960): 217-49. David Ayalon, "al-Djabartī," in Encyclopaedia of Islam, $2^{\text {nd }}$ ed., ed. B. Lewis, Ch. Pellat and J. Schacht, http://dx.doi.org.lama.univ-amu.fr/10.1163/1573-3912_islam_SIM_1894

${ }^{3}$ Al-Gabartī, 'Ajā'ib al-āthār fí l-tarājim wa l-akhbār, ed. 'Abd al-Raḥīm 'Abd al-Raḥmān 'Abd al-Rahīm (Cairo, Egypt: Mihrjān al-qirā'a li-l-jamī', 2003), 2:604. Translation is mine. See also Ch. Wendell and M. Fishbein, trans., 'Abd al-Raḥmān al-Jabartī's History of Egypt (Stuttgart, Germany: Steiner, 1994), 1:645. In this article I keep the Egyptian spelling "al-Gabartī" in order to distinguish the late Ottoman writer from his fellow countrymen who bore the nisba "al-Jabartī" in the later Middle Ages.

${ }^{4}$ Zayla' is a port city in present-day Somaliland. It is already mentioned by Yãqūt al-Rūmī (1179-1229 CE) as a place inhabited by Muslim people on the edge of Abyssinia: Yāqūt al-Rūmī, Mu jam al-buldān, ed. Farīd 'Abd al-'Azīz al-Jundī (Beirut, Lebanon: Dār al-kutub al-ilmiyya), 3:184-85, n. 6151. See also A. Rouaud, "Zayla'," in Bearman, Encyclopaedia of Islam; François-Xavier Fauvelle-Aymar, Bertrand Hirsch, Régis Bernard and Frédéric Champagne, "Le port de Zeyla et son arrière-pays au Moyen Âge. Investigations archéologiques et retour aux sources écrites," in Espaces musulmans de la Corne de I'Afrique au Moyen Âge, Annales d'Éthiopie, hors-série 1, ed. François-Xavier Fauvelle-Aymar and Bertrand Hirsch (Paris: De Boccard, Centre Français des Études Éthiopiennes, 2011), 27-74. On the association between the "Bilād Zayla" and the "Bilād al-Jabart," see below.

5 "Hați" is the Arabic translation of a ge'ez title, used in Arabic literature to refer to the Christian king of Abyssinia since at least the thirteenth century. See Julien Loiseau, "The Hați and the Sultan: Letters and Embassies from Abyssinia to the Mamluk Court," in Mamluk Cairo: A Crossroad for Embassies. Studies on Diplomacy and Diplomatics, eds. F. Bauden and M. Dekkiche (Leiden, The Netherlands: Brill, 2019), 63857.

${ }^{6}$ Unlike Zayla', al-Jabart is not recorded as a place name in the Mu'jam al-buldān of Yãqut al-Rūmì (11791229). See also E. Ullendorff, "Diabart," in Bearman, Encyclopaedia of Islam.

${ }^{7}$ Gabartī, 'Ajā'ib al-āthār, 2:604-36; Wendell and Fishbein, History of Egypt, 644-84.

${ }^{8}$ Nasser Rabbat, "Riwāk,," in Bearman, Encyclopaedia of Islam.

${ }^{9}$ Compare with Irfana Hashmi, "The Development of a Locker System at al-Azhar," Islamic Law and Society 25 (2018): 13.

${ }^{10}$ The Travels of Ludovico di Varthema in Egypt, Syria, Arabia Deserta and Arabia Felix, in Persia, India, and Ethiopia, A.D. 1503 to 1508, translated from the original Italian edition of 1510 with a preface, by John Winter Jones, and edited with notes and an introduction by George Percy Badger (London: Hakluyt
} 
Society, 1863), 37-38. In the wording of this early sixteenth-century travelogue, "Ethiopia" stands for the whole Horn of Africa, "India Minor" likely stands for the Indo-gangetic region, and "India Major" for the rest of the Indian subcontinent.

${ }^{11}$ Ayalon, "The Historian al-Jabartī and his Background"; Ayalon, "al-Djabartī."

12 Julien Loiseau, Reconstruire la Maison du sultan. Ruine et recomposition de l'ordre urbain au Caire, 1350-1450 (Cairo, Egypt: Institut français d'archéologie orientale, 2010), 2:434-45.

${ }^{13}$ Al-Maqrīzī, Al-Mawā'iz wa-l-i'tibār fí dhikr al-khițaț wa-l-āthār, ed. Ayman Fu'ad Sayyid (London: alFurqān Islamic Heritage Foundation, 2004), 4.1:106-7. For information of Sūdūn al-Ẓāhirī, known as "alQāộī," see Ibn Taghrī Birdī, Al-Manhal al-șāfí wa-l-mustawfï ba'd al-Wāfĩ (Cairo, Egypt: Dār al-kutub almișriyya, 1956-2013), 6:149-51.

${ }^{14}$ Maqrīzī, Kitāb al-Sulūk li-ma'rifat duwal al-mulūk, ed. Sa'īd 'Abd al-Fattāḥ 'Āshūr (Cairo, Egypt: Dār alkutub, 1972), 4.1:319; Ibn Ḥajar al-'Asqalānī, Inbā' al-Ghumr bi-anbā' al-'umr, ed. Ḥasan Ḥabashī (Cairo, Egypt: Lajnat iḥyā' al-turāth al-islāmī, 1994), 3:74. See also Carl F. Petry, The Civilian Elite of Cairo in the Later Middle Ages (Princeton, NJ: Princeton University Press, 1981), 334. On the importance of lockers (khazā'in, sing. khizāna) in al-Azhar internal and material organization, see Hashmi, "The Development of a Locker System at al-Azhar" - the events of 1415 are mentioned on 26, n. 53.

${ }^{15}$ Maqrīzì, Khițaț, 4.1:106. On the social meaning of faqīr (pl. fuqarā'), see Adam Sabra, Poverty and Charity in Medieval Islam: Mamluk Egypt, 1250-1517 (Cambridge: Cambridge University Press, 2000), 917.

${ }^{16}$ Maqrīzī, Khițaț, 4.1:102-3; al-Suyūțī, Husn al-muḥāḍara fĩ ta'rīkh Mișr wa l-Qāhira, ed. Muḥammad Abū I-Faḍl Ibrāhīm (Cairo, Egypt: Dār iḥyā' al-kutub al-'arabiyya, 1968), 2:251-52; Julien Loiseau, "The City of Two Hundred Mosques: Friday Worship and Its Spread in the Monuments of Mamluk Cairo," in The Arts of the Mamluks in Egypt and Syria: Evolution and Impact, ed. D. Behrens-Abouseif (Göttingen, Germany: V \& R Unipress, 2012), 184-85.

${ }^{17}$ Maqrīzī, Khițaț, 4.1:100-2.

${ }^{18}$ Jonathan P. Berkey, The Transmission of Knowledge in Medieval Cairo: A Social History of Islamic Education (Princeton, NJ: Princeton University Press, 1992), 51.

${ }^{19}$ Nasser Rabbat, "Al-Azhar Mosque: An Architectural Chronicle of Cairo's History," Muqarnas 13 (1996): 45-67, reprinted in Nasser Rabbat, Mamluk History through Architecture: Monuments, Culture and Politics in Medieval Egypt and Syria (London: I.B. Tauris, 2010), 89-91; Petry, The Civilian Elite of Cairo, 334.

${ }^{20}$ Al-Sakhāwī, Al-Daw' al-lāmi' li-ahl al-qarn al-tāsi', 12 vols. (Cairo, Egypt: Maktabat al-Qudsī, 1934-36). On some occasions, al-Sakhāwī mentions the "students among the people of al-Azhar" (al-țalaba min alAzhariyyīn) or the "greatest among the people of al-Azhar" (qudamä' al-Azhariyyīn), 1:377, 11:197. See also al-Șayrafī (1416-1495), Inbā' al-hașr bi-anbā' al-'așr, ed. Ḥasan Ḥabashī (Cairo, Egypt: al-Hay'a almișriyya al-'āmma li-l-kitāb, 2002), 341 (ahl Jāmi 'al-Azhar). The permanent residents of al-Azhar (mujāwirī al-Azhariyyīn) did have their own graveyard (turba) in the fifteenth century: Sakhāwī, Daw', 9:255, n. 605.

${ }^{21}$ Jean-Claude Garcin, "L'insertion sociale de Sha 'rānī dans le milieu cairote (d'après l'analyse des Ṭabaqāt de cet auteur," Colloque international sur l'histoire du Caire, 27 mars-5 avril 1969 (Cairo, Egypt: Ministry of Culture of the Arab Republic of Egypt, 1969), 159-68. See also Hashmi, "The Development of a Locker System at al-Azhar," 12.

${ }^{22}$ Loiseau, Reconstruire la Maison du sultan, 113-30.

${ }^{23}$ Sabra, Poverty and Charity in Medieval Islam, 87. See also al-Șayrafī, Inbā' al-hașr, 488.

${ }^{24}$ Maqrīzī, Khițaț, 4.1:106. Discussing this quotation of al-Maqrīzī, Petry only mentions students "drawn from Iran, Egypt, and the Maghrib" and lets the "natives of Zayla" (zayāli 'a) go strikingly unremarked. Petry, The Civilian Elite of Cairo, 334. The same is true in the section of the book devoted to "Migration to Cairo from Other Areas of the Muslim World," where Petry describes "Habashis" as a group encompassing 
all the black slaves imported from "East Africa and the Upper Nile Valley," but does not mention any native Muslims from the Horn in fifteenth-century Cairo (77). See also Jacques Jomier, "Al-Azhar," in Encyclopaedia of Islam, $2^{\text {nd }}$ ed., ed. B. Lewis, Ch. Pellat and J. Schacht, who points out that Maqrīzi "mentions 750 provincial or foreign inhabitants, ranging from Maghribīs to Persians, as residing in the mosque."

25 'Alī Pasha Mubārak, Al-Khițaț al-tawfíqiyya al-jadīda li-Mișr al-Qāhira wa mudunihā wa bilādihā alqadīma wa-I-shahīra (Cairo, Egypt: Bulaq, 1888), 4:20-25; 'Abd al-'Azīz al-Shanāwī, "Arwiqat al-Azhar. Qiț'at min ta'rīkhihi wa maẓhar li-infitāḥihi 'alā al-ālam al-islāmī 'ibr ta'rīkhihi al-'ilmī al-ḥāfil," in Dirāsāt fí I-ḥị̂āra al-islāmiyya bi-munāsabat al-qarn al-khāmis 'ashar al-hijrī (Cairo, Egypt: al-Hay'a al-mișriyya al'āmma li-I-kitāb, 1985), 4-123; Hashmi, "The Development of a Locker System at al-Azhar," 14-18.

${ }^{26}$ Shanāwī, "Arwiqat al-Azhar," 16-23.

${ }^{27}$ Muḥammad 'Abd al-'Az̄ìm al-Khūlī, Al-Azhar al-sharīf wa al-sudāniyyūn fĩ al-'așr al-mamlūkī: 648-923 AH/1250-1517 CE (Cairo, Egypt: Maktabat al-thaqāfa al-dīniyya, 2011), 216-220: fraternities (riwāq) hosting students from sub-Saharan origins in the Mamluk period are listed, but for most of them foundation dates are missing. Note that the list includes madrasas along with riwāqs.

${ }^{28} \mathrm{Ibn}$ al-Furāt, Ta'rīkh al-duwal wa-I-mulūk, ed. Qusțantīn Zurayq and Najla 'Izz al-Dīn (Beirut, Lebanon: 1938), 9:474 (obituary notice of a North African scholar who died in 799 AH/1396 CE).

${ }^{29}$ Ibn Khaldūn, Kitāb al-Ta'rīf, ed. Muḥammad b. Tāwīt al-Ṭanjī (Cairo, Egypt: al-Hay'a al-āmma li-qușūr al-thaqāfa, 2003), 248; Maqrīzī, Sulūk, 3.3:480.

${ }^{30}$ Maqrīzī, Khițaț, 4.1:104. See also Gaston Wiet, Matériaux pour un Corpus Inscriptionum Arabicarum, part. I, Egypte, t. 2, fasc. 2 (Cairo, Egypt: IFAO, 1929), Mémoires de I'Institut Français d'Archéologie Orientale 52, 115-18.

${ }^{31}$ Sabra, Poverty and Charity, 87. Khūlī, Al-Azhar al-sharīf wa al-sudāniyyūn, 116.

${ }^{32}$ Hashmi, "The Development of a Locker System at al-Azhar," 17, n. 18.

${ }^{33}$ The following data are the result of a digital analysis of al-Sakhāwī's Daw' al-lāmi '. I warmly thank RenéVincent du Grandlaunay (IDEO, Cairo) for his invaluable help in this matter.

${ }^{34}$ Sakhāwī, Daw', 1:361-62; 3:108, n. 429, 271, n. 1027; 7:180, n. 429; 8:150, n. 353; :9:212, n. 520; 10:113, n. 424.

${ }^{35}$ Șayrafī, Inbā' al-hașr, 132.

${ }^{36}$ Sakhāwī, Daw', 1:377; 3:171, n. 659; 4:80, n. 233.

${ }^{37}$ Sakhāwī, Daw', 4:281, n. 745.

${ }^{38}$ Mubārak, Al-Khițațal-tawfíqiyya, 4:23; Wiet, Matériaux pour un Corpus Inscriptionum Arabicarum, 12021.

${ }^{39}$ Sakhāwī, Daw', 4:262, n. 686; 7:2, n. 1; 11:203. Khūlī mentions the Riwāq al-Jabart without providing datation. Khūlī, Al-Azhar al-sharīf wa al-sudāniyyūn, 217-218.

${ }^{40}$ Shanāwī gives credit to Sultan al-Ashraf Qāytbāy (r. 1468-1496) for refurbishing the Riwāq al-Maghāriba (the living-quarter of the Maghrebians) and for establishing the Riwāq al-Shawām (Syrian students) and the Riwāq al-Atrāk (Anatolian students) on the occasion of the restoration works he ordered in al-Azhar. Shanāwī, "Arwiqat al-Azhar," 16-18. See also Rabbat, "Al-Azhar Mosque," 90. But the inscription quoted by Shanāwī in relation with the Riwāq al-Maghāriba does not mention the name nor the nature of the place refurbished. Moreover, the closest witness of Qāytbāy's restoration works in al-Azhar, the Cairene chronicler Ibn Iyās (1448-1524), does not mention among his achievements the building of new arwiqa. Ibn Iyās, Badā'i' al-zuhūr fĩ waqā'i' a-duhūr, $2^{\text {nd }}$ ed., ed. Muḥammad Mustafā (Cairo, Egypt: al-Hay'a almișriyya al-āmma li-l-kitāb, 1982-84), 3:124, 306. There is no evidence of the Riwāq al-Shawām or the Riwāq al-Atrāk, according to fifteenth-century sources. 
${ }^{41}$ See, for instance, Emeri Van Donzel, "Ibn al-Jawzī on Ethiopians in Baghdad," in The Islamic World from Classical to Modern Times: Essays in Honor of Bernard Lewis, ed. C. E. Bosworth, Ch. Issawi, R. Savory and A. I. Udovitch (Princeton, NJ: Darwin Press, 1989), 113-19.

${ }^{42}$ Carl F. Petry, "From Slaves to Benefactors: the Habashis of Mamluk Cairo," Sudanic Africa 5 (1994): 5968; Shaun Marmon, Eunuchs and Sacred Boundaries in Islamic Society (Oxford: Oxford University Press, 1995); Jo Van Steenbergen, "Mamluk Eunuchs, Habašis and Waqf in the 1340s," in Egypt and Syria in the Fatimid, Ayyubid and Mamluk Eras V: Proceedings of the 11th, 12th and 13th International Colloquium organized at the Katholieke Universiteit Leuven in May 2002, 2003 and 2004, ed. Urbain Vermeulen and Kristof D'Hulster. Orientalia Lovaniensia Analecta 169 (Louvain: Peeters, 2007), 539-552.

${ }^{43}$ In the following lines, the identification of the Zayāli $a$ and Jabartiyya in fourteenth-century Cairo is based on a provisional survey and ongoing research, and does not claim to be exhaustive. The database of the ERC project HornEast will provide a more comprehensive list in the near future. See https://horneast.hypotheses.org/

${ }^{44}$ Ibn Ḥajar al-'Asqalānī, Al-Durar al-kāmina fĩ a yān al-ma'a al-thāmina (Hyderabad, 1929-1931), 3:446447, n. 2596. Khūlī, Al-Azhar al-sharif wa al-sudāniyyūn, 266 (where the same figure appears twice).

${ }^{45}$ Suyūțī gives him a slighlty different nasab and a second nisba (Fakhr al-Dīn 'Uthmān b. 'Alī b. Mihjan alBāri'ī al-Zayla'ī) but dates are the same. Suyūțī, Husn al-muhạdạara, 1:470, n. 36. I have been unable to identify so far the place to which the nisba al-Bāri'i actually refers: it might be a place name from the Horn of Africa. On al-Nasafï, see I. Poonawala, A. J. Wensinck, and W. Heffening, "al-Nasafi," in C. E. Bosworth, E. van Donzel, W. P. Heinrichs and Ch. Pellat ed., Encyclopaedia of Islam.

${ }^{46}$ Wiet, Matériaux pour un Corpus Inscriptionum Arabicarum, 69-70, n. 564; Thesaurus d'épigraphie islamique, n. 21402, www.epigrahie-islamique.org. I warmly thank Robin Seignobos (IFAO) for pointing out this reference. In addition to the script, which suggests the Ottoman era, its narrative and descriptive phrasing is inconsistent with a fourteenth-century epitaph. The mention of Zayla' as a "village from the district of Abyssinia" (wa Zayla qarya bi-nāhiyat al-Habasha) suggests that at the time of its drafting the nisba al-Zayla'i was no longer familiar in Egypt. It is most likely that in Ottoman times, Muslims from the Horn of Africa only bore the nisba al-Jabartī.

${ }^{47}$ Suyūțī, Husn al-muḥạ̣̄ara, 1:359, n. 90. Khūlī, Al-Azhar al-sharīf wa al-sudāniyyūn, 265-266 (where the same figure appears twice).

${ }^{48}$ Ibn H.ajar, Al-Durar al-kāmina, 3:446.

${ }^{49}$ An epitaph bearing the name of one Muhammad b. 'Abd al-Raḥmān b. al-Jabartī, found in Mecca in the graveyard of al-Mu'allā, has been roughly dated, according to its script and style, from the third century AH/tenth century CE: Nāșir b. 'Alī al-Ḥarithī, Ahjār shāhidiyya ghayr manshūra min matḥaf al-āthār wa Iturāth bi-Makka al-mukarrama (Riyadh, Saudi Arabia: 2007), 122-23, n. 48; Thesaurus d'épigraphie islamique, n. 32415. I have been unable so far to see a picture of the inscription and therefore I am unable to confirm or deny the dating.

${ }^{50}$ Ibn Ḥajar, Inbā' al-ghumr, 1:284; Ibn Taghrī Birdī, al-Nujūm al-zāhira fí mulūk Mișr wa-l-Qāhira (Cairo, Egypt: Dār al-kutub al-mișriyya, 1963-72), 11:194. Note that this inquiry on the Zayāli'a and Jabartiyya in Egypt and the Middle East is a work in progress.

${ }^{51}$ Sakhāwī, Daw', 6:325-26, n. 1062; 8:209, n. 548; 8:234, n. 629; 9:161, n. 404.

52 Sakhāwī, Daw', 1:245-46. See also Howayda N. al-Harithy, "Turbat al-Sitt: An Identification," in The Cairo Heritage. Essays in Honor of Laila Ali Ibrahim, ed. Doris Behrens-Abouseif (Cairo, Egypt: American University in Cairo Press, 2000), 103-22.

${ }^{53}$ Maqrīīi Sulūk, 3:2, 936-37. Ibn Taghrī Birdī, al-Nujūm, 12:104. See Loiseau, Reconstruire la Maison du sultan, 1:317-18.

${ }^{54}$ Gabartī, 'Ajā'ib al-āthār, 2:605. 
${ }^{55}$ The same is true elsewhere in the Middle East. In 778 AH/1376 CE Shaykh Sirāj al-Dīn 'Umar al-Zayla ī alMaqdisī (from Bayt al-Maqdis, Jerusalem), "one of the best scholars of Jerusalem" died in that city. He was buried in the Māmilā cemetery within the Qalandar sufis' graveyard. Al-'Ulaymī, Al-Uns al-jalīl bita'rïk al-Quds wa-I-Khalīl (Cairo, Egypt: without publisher or date), 2:159-60.

${ }^{56}$ See the comprehensive study of Yãqūt al-Ḥabashī's life and hagiography by Giuseppe Cecere in this issue.

${ }^{57}$ Ibn Ḥajar, Inbā' al-ghumr, 1:177. Maqrīzī, Sulūk, 3.1:340-41.

${ }^{58} \mathrm{Ibn}$ al-Furāt, Ta'rīkh, 9:289. See also Richard McGregor, Sanctity and Mysticism in Medieval Egypt: The Wafa' Șüfi Order and the Legacy of Ibn 'Arabi (Albany: State University of New York Press, 2004).

${ }^{59}$ Jean-Claude Garcin and Mustapha Anouar Taher, "Un ensemble de waqfs du IX $/ \mathrm{XV}^{\mathrm{e}}$ siècle en Égypte: les actes de Jawhar al-Lâlâ," Res Orientales 6 (1994), special issue Itinéraires d'Orient. Hommages à Claude Cahen, ed. R. Curiel and R. Gyselen: 309-23. Jean-Claude Garcin and Mustapha Anouar Taher, "Les waqfs d'une madrasa du Caire au XV siècle. Les propriétés urbaines de Ǧawhar al-Lālā," in Le waqf dans l'espace islamique. Outil de pouvoir socio-politique, ed. R. Deguilhem (Damascus, Syria: IFEAD, 1995), 151-86. JeanClaude Garcin and Mustapha Anouar Taher, "Enquête sur le financement d'un waqf égyptien du XV siècle: les comptes de Jawhar al-Lālā," JESHO 38, no. 3 (1995): 262-304.

${ }^{60} \mathrm{Garcin}$ and Taher, "Un ensemble de waqfs du IXe/XV siècle," 318. Copper dirhams (dirhām min fulūs) were the Egyptian currency since the beginning of the fifteenth century. These alms of 5,000 copper dirhams to the residents of the riwāq for the festivities of the month of Ramaḍan should be compared to the monthly salary (150 copper dirhams) of the muezzins of Jawhar's madrasa on the same date, a parttime job often held concurrently, or to the monthly spidends of the orphans (480 copper dirhams). Garcin and Taher, "Enquête sur le financement," 284.

${ }^{61}$ Ibn Taghrī Birdī, Manhal, 5:36-38.

62 Garcin and Taher, "Un ensemble de waqfs du Ix / $\mathrm{xV}$ e siècle," 310-13. See also David Ayalon, "The Eunuchs in the Mamluk Sultanate," in Studies in Memory of Gaston Wiet, ed. Myriam Rosen-Ayalon (Jerusalem: Hebrew University, 1977), 267-95, reprint in The Mamlūk Military Society (London: Variorum Reprints, 1979). David Ayalon, Eunuchs, Caliphs and Sultans: A Study of Power Relationships (Jerusalem, Israel: Magnes Press, Hebrew University, 1999).

${ }^{63}$ Ibn Taghrī Birdī, Manhal, 5:38-42. Doris Behrens-Abouseif, Practising Diplomacy in the Mamluk Sultanate: Gifts and Material Culture in the Medieval Islamic World (London: IB Tauris, 2014); Marie-Laure Derat, "Dawit II," Encyclopaedia Aethiopica, ed. Siegbert Uhlig (Wiesbaden, Germany: Harrassovitz Verlag, 2005), 2:112-13.

${ }^{64}$ Rabbat, "Al-Azhar Mosque," 89-90.

${ }^{65}$ Gaston Wiet, "Les relations égypto-abyssines sous les sultans mamlouks," Bulletin de la société d'archéologie copte 4 (1938): 124-25. Loiseau, "The Ḥați and the Sultan."

${ }^{66} \mathrm{I}$ 'm currently preparing a critical edition of this letter. See al-Șayrafī, Nuzhat al-nufūs wa-l-abdān fi tawārīkh al-zamān, ed. Ḥasan Ḥabashī (Cairo, Egypt: al-Hay'a al-mișriyya al-'āmma li-l-kitāb, 1994), 4:28188; Al-Sakhāwī, Al-Tibr al-masbūk fĩ dhayl al-Sulūk, ed. Najwā Mușțafā Kāmil and Labība Ibrāhīm Muștafā (Cairo, Egypt: Dār al-kutub wa-I-wathā'iq al-qawmiyya, 2002-2007), 1:165-70.

${ }^{67}$ Șayrafī, Nuzhat al-nufūs, 4:287; Sakhāwī, Tibr, 1:168.

${ }^{68}$ Loiseau, "The Ḥațī and the Sultan."

${ }^{69}$ John L. Meloy, Imperial Power and Maritime Trade: Mecca and Cairo in the Later Middle Ages (Chicago: Chicago University Press, 2010); Éric Vallet, L'Arabie marchande. État et commerce sous les sultans Rasūlides du Yémen, 626-858/1229-1454 (Paris: Publications de la Sorbonne, 2010).

${ }^{70}$ Sakhāwī, Daw', 6:53, n. 147, 60, n. 190.

${ }^{71}$ Ibid., 3:119, n. 455. 
72 lbid., 6:53, n. 147.

${ }^{73}$ Éric Vallet, Marchands vénitiens en Syrie à la fin du XV siècle (Paris: ADHE, 1999).

${ }^{74}$ Garcin and Taher, "Un ensemble de waqfs du IX $/ \mathrm{XV}^{\mathrm{e}}$ siècle en Égypte," 311-13; Loiseau, Reconstruire la Maison du sultan, 203-5.

${ }^{75}$ Gabartī, 'Ajā'ib al-āthār, 2:605. Wendell and Fishbein, History of Egypt, 645 (where "al-Malik al-Z̄āhir Baybars" must be corrected to "al-Malik al-Z̄āhir Barqūq").

${ }^{76}$ Ibn Iyās, Badā'i 'al-zuhūr, 3:124; Rabbat, "Al-Azhar Mosque," 90.

${ }^{77}$ The last date mentioned in 'Alī al-Jabartī's biography by al-Sakhāwī is 878 AH/1473-74 CE. 